American Journal of Animal and Veterinary Sciences 5 (1): 20-26, 2010

ISSN 1557-4555

(C) 2010 Science Publications

\title{
Change in Growth Performance and Liver Function Enzymes of Broiler Chickens Challenged with Infectious Bursal Disease Virus to Dietary Supplementation of Methionine and Threonine
}

\author{
${ }^{1}$ Elham Maroufyan, ${ }^{1}$ Azhar Kasim, ${ }^{1}$ Seyed Reza Hashemi, \\ ${ }^{1}$ Tech Chwen Loh and ${ }^{2}$ Mohd Hair Bejo \\ ${ }^{1}$ Department of Animal Science, \\ ${ }^{2}$ Department of Veterinary Pathology and Microbiology, \\ University Putra Malaysia, 43400 UPM, Serdang, Selangor, Malaysia
}

\begin{abstract}
Problem statement: The aim of this study was to verify the effects of methionine and threonine supplementations higher than the NRC recommendation on growth performance, liver function enzymes, blood parameters and immune tissues of broiler chickens challenged with infectious bursal disease. Approach: A total of 450 day-old male broiler chicks were assigned to nine groups. Chickens were fed by three graded levels of DL-methionine [NRC (M1), 2 times NRC (M2) and 3 times NRC (M3)] and three graded levels of L-threonine [NRC (T1), 2 times NRC (T2) and 3 times NRC (T3)] from day 1-42 of age. On day 28, all birds were challenged with a commercial live-IBDV vaccine. Results: Body Weight Gain (BWG) and Feed Intake (FI) and Feed Conversion Ratio (FCR) were significantly influenced by the dietary treatments in starter phase and either methionine or threonine at the highest levels significantly decreased BWG, FI and FCR in broiler chickens. A similar trend by methionine and threonine at the highest levels was noted on BWG and FI in grower phase. The highest level of threonine significantly increased spleen weight on day 28 (pre-challenge) and 14 days post challenge. At 14 days after challenge, dietary supplementation of methionine at NRC recommended level (M1) significantly increased the serum concentrations of Alanine Aminotransferase (ALT), aspartate Aminotransferase (AST) and Lactate Dehydrogenase (LDH). In the T3 group, the serum concentrations of AST and LDH were significantly decreased, whereas the serum uric acid concentration was significantly increased. Conclusion/Recommendations: In conclusion, our data suggest that the methionine and threonine requirement of male broiler chicks is higher for growth performance than was suggested by the last NRC committee and liver function enzymes results showed that methionine and threonine supplementation three times higher than NRC requirements in broiler chickens has not toxic potential.
\end{abstract}

Key words: Methionine, threonine, broiler, infectious bursal disease, performance, liver enzyme

\section{INTRODUCTION}

Methionine and threonine are regarded as to be the first and third limiting amino acids in broilers fed practical corn-soybean meal diets (Ojano-Dirain and Waldroup, 2002). Optimal levels of these amino acids are needed to support optimum growth and health of broilers. Nutrient requirement standards have been reported by the National Research Council (NRC, 1994) and through more than 25 years due to genetic selection, management practice and feed formulation changes birds have more rapid growth and better performance than previous years (Havenstein et al., 1994; Williams et al., 2000). On the other hand, NRC recommendation are usually based on the needs of healthy birds under ideal condition, but birds in commercial systems are normally exposed to different kinds of stresses, diseases and also the combination of environmental condition. Infectious Bursal Disease (IBD), also known as Gumboro Disease, is one of the most important poultry diseases in the last 30 years. It is a highly contagious viral disease, affecting the immune system of poultry. However, it is often not recognized due to a subclinical form. Affected chickens have reduced antibody response to vaccinations, strong postvaccinal reactions and increased susceptibility to concurrent or secondary infections. It has been reported that amino acids requirements increased in disease and

Corresponding Author: Seyed Reza Hashemi, Department of Animal Science, University Putra Malaysia, 43400 UPM, Serdang, Selangor, Malaysia Tel: 0060196448084/00989111704427 
infectious and infections lead to several changes in amino acid plasma levels (Bhargava et al., 1971). Amino acids are required for the synthesis of a variety of specific proteins (including cytokines and antibodies) and regulate key metabolic pathways of the immune response to infectious pathogens. Dietary levels of certain individual amino acids have been shown to affect immune response (Jeevanandam et al. 1990; Paaw and Davis, 1990). Methionine (Swain and Johri, 2000; Rama Rao et al., 2003; Shini et al., 2005) and threonine (Duval et al. 1991; Ball et al., 1999) are two amino acids that have proven immune regulatory action. There is some evidence that essential amino acid level in the feed higher than of NRC specifications needed to achieve optimal immune system and growth performances (Quentin et al., 2005). Response of liver function enzymes to excessive methionine and threonine more than NRC recommendation have not been reported in broiler chickens challenged with IBD. Therefore, the possibility that excess of methionine and threonine may exert parts of its toxic effects by altering the liver function enzymes should be considered. Hence, it may be necessary for new research to conduct multiple focus and attention to the actual broiler requirements. The present experiment was conducted to determine the effects of dietary methionine and threonine supplementation on performance, liver function enzymes and serum metabolites of broiler chickens challenged with infectious bursal disease.

\section{MATERIALS AND METHODS}

Birds and housing environment: A total of four hundred fifty day-old male broiler chicks (Cobb 500) were obtained from a local hatchery. The chicks were wing-banded, individually weighed and housed in floor pens with wood shavings as litter material. The pens were in a conventional open-sided house with cyclic temperatures (minimum, $24^{\circ} \mathrm{C}$; maximum, $32^{\circ} \mathrm{C}$ ). The relative humidity was between $80-90 \%$. The area of each pen was $1.5 \mathrm{~m}^{2}$. Feed and water were provided ad libitium and lighting was continuous.

Experimental design: Commencing from day one, five replicate pens of 10 chicks each were assigned to one of the nine dietary treatments, giving a total of 45 pens. There were 3 levels of methionine in the form of DLmethionine (NRC (M1), 2 times NRC (M2) and three times NRC (M3)) and three levels of threonine in the form of L-threonine (NRC (T1), 2 times NRC (T2) and 3 times NRC (T3)). Birds aged 0-21 days fed diets containing graded concentrations of methionine (NRC, 0.75 and $1.27 \%$ of diet) and threonine (NRC, 0.82 and
$1.62 \%$ of diet) and diets with similarly graded concentrations of methionine (NRC, 0.49 and $0.88 \%$ of diet) and threonine (NRC, 0.76 and $1.51 \%$ of diet) to birds aged 22-42 days. The basal diets (mash form) were formulated to meet or exceed requirements by the NRC (1994) for broiler chickens (Table 1). No antimicrobial, anticoccidial drugs or feed enzymes were included in the basal diets. The chicks were vaccinated against Newcastle disease (Animal Health, Fort Dodge, Iowa, USA) on day 7 (Intraocular) and on day 21(intranasal).

Challenge protocol: On day 28, all birds were challenged by oral route with a commercial live-IBDV vaccine (V877 strain, Malaysian Vaccines and Pharmaceuticals Sdn. Bhd). The strain was characterized as an intermediate virulent classical strain. The content of the 1000 dose of IBD vaccine vial was reconstituted in $100 \mathrm{~mL}$ distilled water and each bird was inoculated with $1 \mathrm{~mL}$ IBD virus into the lumen of the crop by oral gavage, that finally each bird received a dose ten times greater than the standard IBD vaccine.

Table 1: Ingredients and nutrient composition of diets

\begin{tabular}{|c|c|c|}
\hline Item & $\begin{array}{l}\text { Starter } \\
1-21 \text { days }\end{array}$ & $\begin{array}{l}\text { Finisher } \\
22-42 \text { days }\end{array}$ \\
\hline \multicolumn{3}{|l|}{ Ingredient (\%) } \\
\hline Corn & 45.35 & 50.95 \\
\hline Soybean meal & 43.97 & 38.22 \\
\hline Palm oil & 6.22 & 6.89 \\
\hline Di calcium phosphate & 1.91 & 1.76 \\
\hline Limestone & 1.20 & 1.05 \\
\hline Salt & 0.44 & 0.31 \\
\hline Vitamin and mineral premix ${ }^{1}$ & 0.60 & 0.60 \\
\hline DL-methionine & 0.20 & 0.10 \\
\hline L-threonine & 0.00 & 0.00 \\
\hline Lysine & 0.11 & 0.12 \\
\hline \multicolumn{3}{|c|}{${ }^{2}$ Nutrition composition (calculated) } \\
\hline Crude protein $(\%)$ & 22.00 & 20.00 \\
\hline $\operatorname{ME}\left(\right.$ Mcal kg $\left.{ }^{-1}\right)$ & 3050.00 & 3150.00 \\
\hline Available phosphorus (\%) & 0.45 & 0.42 \\
\hline Calcium $(\%)$ & 1.00 & 0.90 \\
\hline Methionine & 0.50 & 0.38 \\
\hline Lysine & 1.10 & 1.00 \\
\hline Argenine & 1.40 & 1.33 \\
\hline Tryptophane & 0.28 & 0.26 \\
\hline Threonine & 0.80 & 0.74 \\
\hline $\mathrm{Na}$ & 0.20 & 0.74 \\
\hline $\mathrm{Cl}$ & 0.39 & 0.25 \\
\hline $\mathrm{K}$ & 1.02 & 0.92 \\
\hline Crude Fiber & 4.20 & 3.92 \\
\hline DEB meg $\mathrm{Kg}^{-1}$ & 235.00 & 212.00 \\
\hline $\mathrm{Ca} / \mathrm{P}$ & 138.00 & 157.00 \\
\hline
\end{tabular}

${ }^{1}$ : Supplied per kilogram of diet: vitamin A, 1,500 IU; cholecalciferol, $200 \mathrm{IU}$; vitamin E, $10 \mathrm{IU}$; riboflavin, $3.5 \mathrm{mg}$; pantothenic acid, $10 \mathrm{mg}$; niacin, $30 \mathrm{mg}$; cobalamin, $10 \mu \mathrm{g}$; choline chloride, 1,000 mg; biotin, $0.15 \mathrm{mg}$; folic acid, $0.5 \mathrm{mg}$; thiamine $1.5 \mathrm{mg}$; pyridoxine $3.0 \mathrm{mg}$; iron, $80 \mathrm{mg}$; zinc, $40 \mathrm{mg}$; manganese, $60 \mathrm{mg}$; iodine, $0.18 \mathrm{mg}$; copper, $8 \mathrm{mg}$; selenium, $0.15 \mathrm{mg}$; ${ }^{2}$ : Based on NRC (1994) feed composition table 
Performance parameters: The chickens were weighed individually on $\mathrm{d} 1,7,14,21,28,35$ and 42 . Feed intake was recorded weekly and Feed Conversion Ratios (FCR) were calculated. Mortality was recorded daily in each subgroup.

Organ weight: At 28,35 and 42 days of age, eight birds from each treatment were chosen at random, weighed and then slaughtered according to the Islamic method (Halal). The weights of spleen and bursa of Fabricius were recorded. Organ weights were expressed on a relative body weight basis.

Serum metabolites and liver function test: On d 28 and 42 (14 days after challenge), eight birds from each group were chosen at random and blood samples $(4.0 \mathrm{~mL})$ were collected from the brachial vein using a 23 -ga needle. Serum was separated by centrifugation at $3000 \mathrm{~g}$ for $10 \mathrm{~min}$ and stored at $-20^{\circ} \mathrm{C}$ until analysis. Serum creatine, Alkaline Phosphatase (ALP), Alanine Aminotransferase (SGPT or ALT), Aspartate Aminotransferase (SGOT or AST) and Lactate Dehydrogenase (LDH) were measured by specific commercial kits (Roche Diagnostica, Basel, Switzerland) using an autoanalyzer (HITACHI 902 automatic autoanalyzer).

Statistical analysis: The data were analyzed using a two-way ANOVA in a completely randomized design (CRD) in a factorial scheme of $3 \times 3$ (methionine levels $\times$ threonine levels) with the PROC GLM procedure of the Statistical Analysis System (SAS Institute, 2005).
The results were expressed as mean \pm standard error of mean. Statistical significance was considered at $p \leq 0.05$.

\section{RESULTS}

The effects of methionine and threonine on body weight gain (BWG), feed intake (FI) and feed conversation ratio (FCR) in broiler chicken are presented in Table 2. BWG, FI and FCR were significantly influenced by the dietary treatments in starter phase (0-21) and either methionine or threonine at the highest levels significantly decreased BWG, FI and FCR in broiler chickens. A similar trend by methionine and threonine at the highest levels was noted on BWG and FI in grower phase (22-42). No significant difference was seen between treatment groups in grower phase on FCR. There were significant interactions between methionine and threonine on FCR on day 21 and BWG on day 42 (Table 3). Birds were fed with M2T3 M3T2 and M3T3 had an improvement in FCR compare with other groups. The highest BWG was observed in broiler chickens fed M2T1. However, there were no significant differences on BWG between M2T1 and M3T1 birds.

Effect of methionine and threonine on means of relative organ weight of broiler chickens is shown in Table 4. The highest level of threonine significantly increased spleen weight before challenge and 14 days post challenge. There were not statistically significant differences on spleen weight between $\mathrm{T} 2$ and $\mathrm{T} 3$ groups 14 days post challenge. The bursa of Fabricius weights of birds were not affected by methionine and methionine $\times$ threonine interaction.

Table 2: The effects of methionine and threonine on Body Weight Gain (BWG), Feed Intake (FI) and Feed Conversation Ratio (FCR) in broiler chickens challenged with IBD on $\mathrm{d} 28$

\begin{tabular}{|c|c|c|c|c|c|c|}
\hline Main effect & BWG (0-21) & FI $(0-21)$ & FCR $(0-21)$ & BWG (22-42) & FI (22-42) & FCR (22-42) \\
\hline$\overline{\text { M1 }}$ & $751 \pm 7.9^{\mathrm{a}}$ & $1179 \pm 34^{\mathrm{a}}$ & $1.42 \pm 0.02^{\mathrm{a}}$ & $1541 \pm 23$ & $3159 \pm 46^{\mathrm{a}}$ & $2.1 \pm 0.04$ \\
\hline M2 & $762 \pm 6.8^{\mathrm{a}}$ & $1139 \pm 24^{\mathrm{a}}$ & $1.33 \pm 0.02^{\mathrm{b}}$ & $1565 \pm 22$ & $3138 \pm 43^{\mathrm{a}}$ & $2.0 \pm 0.14$ \\
\hline M3 & $663 \pm 8.1^{\mathrm{b}}$ & $950 \pm 29^{b}$ & $1.29 \pm 0.02^{\mathrm{b}}$ & $1496 \pm 30$ & $2741 \pm 78^{\mathrm{b}}$ & $2.0 \pm 0.14$ \\
\hline $\mathrm{T} 1$ & $733 \pm 7.0^{\mathrm{b}}$ & $1175 \pm 35^{\mathrm{a}}$ & $1.45 \pm 0.02^{\mathrm{a}}$ & $1634 \pm 20^{\mathrm{a}}$ & $3175 \pm 44^{\mathrm{a}}$ & $2.0 \pm 0.10$ \\
\hline $\mathrm{T} 2$ & $756 \pm 7.7^{\mathrm{a}}$ & $1107 \pm 28^{\mathrm{b}}$ & $1.31 \pm 0.01^{\mathrm{a}}$ & $1547 \pm 25^{\mathrm{b}}$ & $3005 \pm 76^{\mathrm{b}}$ & $2.0 \pm 0.09$ \\
\hline T3 & $686 \pm 9.6^{\mathrm{c}}$ & $985 \pm 37^{c}$ & $1.30 \pm 0.02^{b}$ & $1421 \pm 26^{\mathrm{c}}$ & $2858 \pm 82^{\mathrm{c}}$ & $2.1 \pm 0.12$ \\
\hline \multicolumn{7}{|c|}{ ANOVA (p-value) } \\
\hline M & $* * *$ & $* * *$ & $* * *$ & NS & $*$ & NS \\
\hline $\mathrm{T}$ & $* * *$ & $* * *$ & $* * *$ & $* * *$ & $*$ & NS \\
\hline $\mathrm{M} \times \mathrm{T}$ & NS & NS & $* *$ & $* *$ & NS & NS \\
\hline
\end{tabular}

Table 3: Means $( \pm$ SEM) Feed Conversion Ratio $($ FCR) and Body Weight Gain $(B W G)$ of broiler chickens where methionine $\times$ threonine interactions were significant

\begin{tabular}{|c|c|c|c|c|c|c|}
\hline \multirow[b]{2}{*}{ Treatments } & \multicolumn{3}{|c|}{ FCR (0-21) } & \multicolumn{3}{|c|}{ BWG (22-42) } \\
\hline & M1 & M2 & M3 & M1 & M2 & M3 \\
\hline$\overline{\mathrm{T} 1}$ & $1.55 \pm 0.02^{\mathrm{ax}}$ & $1.41 \pm 0.02^{\mathrm{bx}}$ & $1.36 \pm 0.02^{\mathrm{bx}}$ & $1551 \pm 28^{\text {bxy }}$ & $1680 \pm 35^{\mathrm{ax}}$ & $1669 \pm 39^{\mathrm{ax}}$ \\
\hline $\mathrm{T} 2$ & $1.30 \pm 0.02^{\mathrm{abz}}$ & $1.34 \pm 0.03^{\text {ay }}$ & $1.27 \pm 0.02^{\text {by }}$ & $1623 \pm 43^{x}$ & $1538 \pm 33^{y}$ & $1481 \pm 51^{y}$ \\
\hline $\mathrm{T} 3$ & $1.40 \pm 0.02^{\text {ay }}$ & $1.24 \pm 0.02^{\mathrm{bz}}$ & $1.23 \pm 0.03^{\text {by }}$ & $1447 \pm 47^{y}$ & $1478 \pm 39^{y}$ & $1337 \pm 50^{z}$ \\
\hline
\end{tabular}


American J. Animal \& Vet. Sci., 5 (1): 20-26, 2010

Table 4: Effect of methionine and threonine on means of relative organ weight of broiler chickens challenged with IBD on day 28

\begin{tabular}{|c|c|c|c|c|c|c|}
\hline \multirow[b]{2}{*}{$\begin{array}{l}\text { Main } \\
\text { effect }\end{array}$} & \multicolumn{3}{|l|}{ Spleen } & \multicolumn{3}{|c|}{ Bursa of Fabricius } \\
\hline & $\begin{array}{l}28 \text { days } \\
\text { pre-challenge }\end{array}$ & $\begin{array}{l}7 \text { days } \\
\text { post challenge }\end{array}$ & $\begin{array}{l}14 \text { days } \\
\text { post challenge }\end{array}$ & $\begin{array}{l}28 \text { days } \\
\text { pre-challenge }\end{array}$ & $\begin{array}{l}7 \text { days } \\
\text { post challenge }\end{array}$ & $\begin{array}{l}14 \text { days } \\
\text { post challenge }\end{array}$ \\
\hline$\overline{\text { M1 }}$ & $0.15 \pm 0.021$ & $0.19 \pm 0.027$ & $0.16 \pm 0.016$ & $0.18 \pm 0.018$ & $0.090 \pm 0.011$ & $0.058 \pm 0.007$ \\
\hline M2 & $0.19 \pm 0.031$ & $0.20 \pm 0.027$ & $0.17 \pm 0.013$ & $0.17 \pm 0.013$ & $0.090 \pm 0.006$ & $0.048 \pm 0.002$ \\
\hline M3 & $0.17 \pm 0.025$ & $0.18 \pm 0.027$ & $0.14 \pm 0.013$ & $0.17 \pm 0.016$ & $0.086 \pm 0.009$ & $0.044 \pm 0.003$ \\
\hline $\mathrm{T} 1$ & $0.13 \pm 0.005^{b}$ & $0.21 \pm 0.027$ & $0.12 \pm 0.010^{\mathrm{b}}$ & $0.20 \pm 0.015$ & $0.083 \pm 0.004$ & $0.049 \pm 0.007$ \\
\hline $\mathrm{T} 2$ & $0.13 \pm 0.015^{\mathrm{b}}$ & $0.20 \pm 0.027$ & $0.16 \pm 0.012^{\mathrm{ab}}$ & $0.17 \pm 0.015$ & $0.096 \pm 0.011$ & $0.059 \pm 0.003$ \\
\hline T3 & $0.25 \pm 0.033^{\mathrm{a}}$ & $0.17 \pm 0.027$ & $0.18 \pm 0.015^{\mathrm{a}}$ & $0.16 \pm 0.015$ & $0.088 \pm 0.011$ & $0.049 \pm 0.003$ \\
\hline \multicolumn{7}{|c|}{ ANOVA (p-value) } \\
\hline M & NS & NS & NS & NS & NS & NS \\
\hline $\mathrm{T}$ & $* * *$ & NS & $*$ & NS & NS & NS \\
\hline $\mathrm{M} \times \mathrm{T}$ & NS & NS & NS & NS & NS & NS \\
\hline
\end{tabular}

Organ weight data, expressed as percentages of body weight; *: $\mathrm{p}<0.05 ; * *: \mathrm{p}<0.01 ; * * *: \mathrm{p}<0.001$; NS: Non-Significant

Table 5: Effect of methionine and threonine on liver function enzymes and blood parameters in broiler chickens challenged with IBD on day 28

\begin{tabular}{|c|c|c|c|c|c|c|}
\hline Main effect & $\operatorname{ALT}\left(\mathrm{U} \mathrm{L}^{-1}\right)$ & $\operatorname{AST}\left(\mathrm{U} \mathrm{L}^{-1}\right)$ & $\operatorname{ALP}\left(\mathrm{U} \mathrm{L}^{-1}\right)$ & $\mathrm{LDH}\left(\mathrm{U} \mathrm{L}^{-1}\right)$ & Creatinine $\left(\mathrm{mmol} \mathrm{L}^{-1}\right)$ & Uric Acid $\left(\mathrm{umol} \mathrm{L}^{-1}\right)$ \\
\hline \multicolumn{7}{|c|}{28 day of experiment (before challenge) } \\
\hline M1 & $7.5 \pm 0.56$ & $275 \pm 12$ & $3885 \pm 488$ & $2866 \pm 166$ & $26 \pm 1.1$ & $225 \pm 17$ \\
\hline M2 & $8.9 \pm 0.53$ & $295 \pm 21$ & $3147 \pm 266$ & $2504 \pm 190$ & $33 \pm 1.7$ & $279 \pm 31$ \\
\hline M3 & $6.6 \pm 0.72$ & $255 \pm 9$ & $3405 \pm 340$ & $2660 \pm 184$ & $29 \pm 1.5$ & $260 \pm 25$ \\
\hline $\mathrm{T} 1$ & $6.7 \pm 0.72$ & $274 \pm 20$ & $3668 \pm 344$ & $2654 \pm 215$ & $30 \pm 1.7$ & $269 \pm 24$ \\
\hline $\mathrm{T} 2$ & $7.6 \pm 0.66$ & $270 \pm 13$ & $3737 \pm 522$ & $2740 \pm 131$ & $30 \pm 1.8$ & $286 \pm 24$ \\
\hline $\mathrm{T} 3$ & $8.6 \pm 0.46$ & $282 \pm 11$ & $3031 \pm 232$ & $2637 \pm 196$ & $29 \pm 1.5$ & $210 \pm 19$ \\
\hline \multicolumn{7}{|c|}{ ANOVA (p-value) } \\
\hline M & Ns & Ns & Ns & Ns & Ns & Ns \\
\hline $\mathrm{T}$ & Ns & Ns & Ns & Ns & Ns & Ns \\
\hline $\mathrm{M} \times \mathrm{T}$ & Ns & Ns & Ns & Ns & Ns & Ns \\
\hline \multicolumn{7}{|c|}{42 day of experiment ( 14 days after challenge) } \\
\hline M1 & $7.4 \pm 0.3^{\mathrm{a}}$ & $390 \pm 27^{\mathrm{a}}$ & $2479 \pm 472$ & $3604 \pm 312^{\mathrm{a}}$ & $30 \pm 1.5$ & $356 \pm 22$ \\
\hline M2 & $6.2 \pm 0.6^{\mathrm{b}}$ & $304 \pm 11^{\mathrm{b}}$ & $2572 \pm 321$ & $2577 \pm 218^{\mathrm{b}}$ & $28 \pm 0.9$ & $367 \pm 31$ \\
\hline M3 & $6.0 \pm 0.2^{\mathrm{b}}$ & $309 \pm 8^{\mathrm{b}}$ & $2082 \pm 284$ & $2900 \pm 196^{\mathrm{b}}$ & $30 \pm 1.0$ & $344 \pm 31$ \\
\hline $\mathrm{T} 1$ & $6.7 \pm 0.3$ & $362 \pm 33 \mathrm{a}$ & $2303 \pm 244$ & $2959 \pm 328^{\mathrm{a}}$ & $29 \pm 1.0$ & $300 \pm 23^{\mathrm{b}}$ \\
\hline $\mathrm{T} 2$ & $6.9 \pm 0.4$ & $344 \pm 13^{\mathrm{a}}$ & $2348 \pm 462$ & $3470 \pm 219^{\mathrm{ab}}$ & $29 \pm 0.7$ & $346 \pm 23^{\mathrm{b}}$ \\
\hline $\mathrm{T} 3$ & $6.1 \pm 0.6$ & $296 \pm 9^{\mathrm{b}}$ & $2482 \pm 335$ & $2649 \pm 187^{b}$ & $30 \pm 1.6$ & $421 \pm 26^{\mathrm{a}}$ \\
\hline \multicolumn{7}{|c|}{ ANOVA (p-value) } \\
\hline M & $* *$ & $* * *$ & NS & $* *$ & NS & NS \\
\hline $\mathrm{T}$ & Ns & $* *$ & NS & $*$ & NS & $* *$ \\
\hline $\mathrm{M} \times \mathrm{T}$ & $* * *$ & $* *$ & NS & $*$ & NS & NS \\
\hline
\end{tabular}

${ }^{\mathrm{a}-\mathrm{c}}$ : Means within a column with different subscripts differ significantly $(\mathrm{p}<0.05)$. *: $\mathrm{p}<0.05 ; * *: \mathrm{p}<0.01 ; * * *: \mathrm{p}<0.001 ;$ NS: Non-Significant

Table 6: Interaction effect of methionine and threonine on ALT, AST and LDH at 14 days post challenge in broiler chickens challenged with IBD on $\mathrm{d} 28$

\begin{tabular}{|c|c|c|c|c|c|c|c|c|c|}
\hline \multirow[b]{2}{*}{ Treatments } & \multicolumn{3}{|c|}{$\operatorname{ALT}\left(\mathrm{U} \mathrm{L}^{-1}\right)$} & \multicolumn{3}{|c|}{$\operatorname{AST}\left(\mathrm{UL}^{-1}\right)$} & \multicolumn{3}{|l|}{$\mathrm{LDH}\left(\mathrm{U} \mathrm{L}^{-1}\right)$} \\
\hline & M1 & M2 & M3 & M1 & M2 & M3 & M1 & M2 & M3 \\
\hline$\overline{\mathrm{T} 1}$ & $6.8 \pm 0.5$ & $7.0 \pm 0.7^{x}$ & $6.0 \pm 0.4$ & $491 \pm 54^{\text {ax }}$ & $314 \pm 33^{b}$ & $286 \pm 10^{\mathrm{b}}$ & $4385 \pm 524^{\mathrm{ax}}$ & $2268 \pm 186^{\text {by }}$ & $2226 \pm 150^{\mathrm{yb}}$ \\
\hline $\mathrm{T} 2$ & $7.0 \pm 0.4$ & $7.7 \pm 0.9^{x}$ & $6.0 \pm 0.6^{\mathrm{b}}$ & $386 \pm 25^{\text {ay }}$ & $311 \pm 8^{\mathrm{b}}$ & $334 \pm 12^{\mathrm{ab}}$ & $3788 \pm 280^{x y}$ & $3481 \pm 393^{x}$ & $3461 \pm 462^{x}$ \\
\hline T3 & $8.4 \pm 0.6^{\mathrm{a}}$ & $4.0 \pm 0.6^{\mathrm{cy}}$ & $6.1 \pm 0.1^{\mathrm{b}}$ & $294 \pm 17^{y}$ & $286 \pm 20$ & $307 \pm 15$ & $2641 \pm 440^{\mathrm{y}}$ & $2292 \pm 356^{\mathrm{y}}$ & $3015 \pm 146^{x y}$ \\
\hline
\end{tabular}

The effect of methionine and threonine on liver function enzymes and blood parameters in broiler chickens challenged with infectious bursal disease virus are shown in Table 5. There was no significant difference between the treatments for blood parameters and liver enzymes on d 28. At 14 days after challenge, dietary supplementation of methionine at NRC recommended level (M1) significantly increased the serum concentrations of ALT, AST and $\mathrm{LDH}$. In the T3 group, the serum concentrations of AST and LDH were significantly decreased, whereas the serum uric acid concentration was significantly increased. There were no significant differences between T2 and T3 groups on LDH. Methionine and threonine interaction had significant effect on serum level of ALT, AST and LDH (Table 6). 


\section{DISCUSSION}

Dietary characteristics can modulate a bird's susceptibility to infectious challenges and subtle influences due to the level of nutrients or the types of ingredients may at times be of critical importance (Klasing, 1998). NRC requirements for amino acids and protein are designed to support maximum growth and production under ideal condition and well maintenance. The recommended levels for methionine and threonin in poultry depend on species, stage, environment condition and level of feed consumption. They are already known that most nutrients are involved in the development of the immune system and its responses. The present findings indicated that birds were fed at the highest level of methionine and threonine had significantly better FCR than those were fed with NRC diet in starter phase and the highest body weight gain was observed in broiler chickens were fed M2T1 and M3T1 diets in grower phase. Improvement of feed efficiency at the highest level of threonine and methionine in initial phase may be explained by several possibilities. First, nutrient requirements of broiler based on recommendation of NRC 1994 and these information related to previous NRC finding but, the present commercial bird is very different from commercial birds were available in last decade so birds have more rapid growth and better performance than previous years due to genetic selection as well as management practice and feed related changes (Chamruspollert et al., 2002). Therefore birds need to more energy and protein to meet their needs. Second, amino acid and protein requirements of broiler chickens are higher in the starter period than grower period (NRC, 1994). Third, nutrition recommended set by NRC are usually based on the need of healthy birds under ideal management but the combination of environment condition and disease increase the requirement for essential nutrient. Fourth, methionine requirement of male broilers is more than NRC (1994) recommendation (Hesabi et al., 2006). Finaly, amino acid interactions such as arginine and methionine in chicks raised at high temperatures likely differ from those raised at ambient temperature (Chamruspollert et al., 2004). In addition, threonine is procures glycin amino acid that was a vital amino acid for maximal chick growth (Almquist and Grau, 1944). It should be noted that glycin affects protein synthesis not only as a building blocks for protein itself, but also is required for the creation of DNA, RNA and uric acid (Ngo and Coon, 1976). It should be noted that although threonine requirement of young chicks has been studied extensively but there is evidence that threonine requirement of the broiler chick affected by protein, amino acid level and source (Robbins, 1987; Koide and Ishibashi, 1995).

Fasuyl and Alertor (2005) reported that better performance can still be obtained with adequate supplementation of essential amino acids especially methionine which has been identified to be in marginal quantities in most poultry diets. Garlich (1985) found that feed conversion was better when methionine was supplemented. A improve in broiler performance when methionine was added to a corn-soybean diet has been reported (Virtanen and Rosi, 1995; Hesabi et al., 2006). In contrary to our result, no significant effects were seen for methionine levels on feed conversion ratio by Meirelles et al. (2003). They, however, observed numerical improvement with the increasing ratio. Furthermore, one report (Thomas et al., 1979) suggests that the requirement of a commercial strain of broiler chicks is near $0.81 \%$ threonine. They studies demonstrate that $0.64 \%$ dietary threonine was insufficient for maximum growth and efficiency of feed utilization by Leghorn chicks. This level of threonine occasionally permitted maximum growth and feed utilization, but usually resulted in significantly poorer performance than the diet containing $0.72 \%$ or more threonine. However, the findings of the current study do not support the previous research by Kidd et al. (1997), Smith and Waldroup (1988) that the NRC (1994) and NRC (1984) estimate on threonine, for 0-3-week-old chicks are too high.

In birds, the spleen is primarily concerned with the immune reactivity belonging to cell-mediated immunity, delayed type of hypersensitivity as well as humoral immunity. Our Results are in disagreement with previous findings by Kidd et al. (2001) and Corzo et al. (2007) in that dietary threonine not influenced spleen organ weights of broilers chickens. These differences might be explained by the threonine concentration were used.

On the other hand, adverse nutritional effects or toxicity have been reported when the diet of an animal, usually a growing animal, is supplemented with a single amino acid, a mixture of amino acids, or a protein of poor nutritional quality (Munro and Goldberg, 1964). The present study showed that uric acid levels increased at the highest level of threonine before challenge. Increase in uric acid excretion on protein ingestion is due to the nuclear disintegration occasioned by the work of digestion. Another theory ascribes the increase to stimulation of purine synthesis. It has been suggested that part of the endogenous uric acid arises by synthesis from protein and carbohydrate and part from the metabolism of cell nuclei (Zwarenstein, 1926). The 
amino acid threonine is an important compound for the production of purines and uric acid is an extremely insoluble purine compound.

It has been demonstrated that the activities of many liver enzymes involved in the catabolism of amino acids decrease when a low protein diet is fed, but increase with high protein intakes (Muramatsu et al., 1971). In our experiment, liver enzymes were not affected by treatment diets on d 28 whereas 14 days post challenge, methionine at NRC recommended level had significant increase in the concentration of ALT, AST and LDH. Furthermore, the highest elevation in serum ALT was observed in M1T3 and also the highest increase in serum AST and LDH levels was noted in M1T1. The findings may also explain that current NRC recommendations for methionine and threonine in broiler are probably not appropriate for broiler health under stress and diseases condition. Although, it should be note that the concentration of ALT, AST and LDH in M1T1 also were in normal range (Chattopadhyay et al., 2006; Marjanovic et al., 1975).

\section{CONCLUSION}

Hence, it can be concluded that the methionine and threonine requirements of broiler breeders would be expected to change substantially as they approach maximum performance under actual farm conditions and they supplementation higher than NRC recommendation in broiler chickens have not toxic potential.

\section{ACKNOWLEDGEMENT}

The researchers would like to express their gratitude to Mr. Mazlan Hamzah and Ponnusamy Muniandy the staff of Animal Science Department of Agriculture Faculty, University Putra Malaysia for their technical assistance during the experimental period.

\section{REFERENCES}

Almquist, H.J. and C.R. Grau, 1944. The amino acid requirements of the chick. J. Nutr., 28: 325-331. http://jn.nutrition.org/cgi/reprint/28/5/325.pdf

Ball, R.O., G. Law, R.F.P. Bertolo and P.B. Pencharz, 1999. Adequate oral threonine is critical for mucin production and mucosal growth by neonatal piglet gut. Am. J. Physiol. Gastrointest. Liver. Physiol. 292:1293-1301. DOI: 10.1152/ajpgi.00221.2006

Bhargava, K.K., R.P. Hanson and M.L. Sunde, 1971. Effects of threonine on growth and antibody production in chickens infected with Newcastle disease virus. Poult. Sci., 50: 710-713. PMID: 5569753
Chamruspollert, M., G.M. Pesti and R.I. Bakalli, 2004. Influence of temperature on the arginine and methionine requirements of young broiler chicks. J. Applied Poult. Res., 13: 628-638. PMID: 5569753

Chamruspollert, M., G.M. Pesti and R.I. Bakalli, 2002. Determination of the methionine requirement of male and female broiler chicks using an indirect amino acid oxidation method. Poult. Sci., 81: 1004-1013. http://ps.fass.org/cgi/reprint/81/7/1004

Chattopadhyay, K., M.K. Mondal and B. Roy, 2006. Comparative efficacy of Dl-methionine and herbal methionine on performance of broiler chicken. Int. J. Poult. Sci., 5: 1034-1039. http://scialert.net/pdfs/ijps/2006/1034-1039.pdf

Corzo, A., M.T. Kidd, W.A. Dozier III, G.T. Pharr and E.A. Koutsos, 2007. Dietary threonine needs for growth and immunity of broilers raised under different litter conditions. J. Applied Poult. Res., 16: 574-582. DOI: 10.3382/japr.2007-00046

Duval, D., C. Demangel, K. Munierjolain, S. Miossec and I. Geahel, 1991. Factors controlling cell proliferation and antibody production in mouse hybridoma cells. Influence of the amino acid supply. Biotechnol. Bioeng., 38: 561-570. DOI: 10.1002/bit.260380602

Fasuyl, A.O. and V.A. Aletor, 2005. Protein replacement value of cassava, (Manihot esculenta, Crantz) leaf protein concentrate in broiler starter: Effect on performance, muscle growth, haematology and serum metabolites. Int. J. Poult. Sci., 4: 339-349. http://www.pjbs.org/ijps/fin352.pdf

Garlich, J.D., 1985. Response of broiler to DLmethionine hydroxy analogue free acid, DLmethionine and L-methionine. Poult. Sci., 64: 1541-84. PMID: 4048050

Havenstein, G.B., P.R. Ferket, S.E. Scheidler and B.T. Larson, 1994. Growth, livability and feed conversion of 1991 VS 1957 broilers when fed "typical" 1957 and 1991 broiler diets. Poult. Sci., 73: 1785-1794. PMID: 7877934

Hesabi, A., H. Nasiri and M. Birjandi, 2006. Effect of supplemental methionine and lysine on performance and carcass yield characteristics in broiler chicks. Proceedings of the 8th Conference on European Poultry, Sep. 10-14, Verona, Italy. http://www.cabi.org/animalscience/Uploads/File/Animal Science/additionalFiles/WPSAVerona\%5C10361.pdf

Jeevanandam, M., D.H. Young, L. Ramais and W.R. Schiller, 1990. Effect of major trauma on plasma free amino acid concentrations in geriatric patients. Am. J. Clin. Nutr., 51: 1040-1050. http://www.ajcn.org/cgi/reprint/51/6/1040

Kidd, M.T., B.J. Kerr and N.B. Anthonya, 1997. Dietary interactions between lysine and threonine in broilers. Poult. Sci., 76: 608-614. http://ps.fass.org/cgi/reprint/76/4/608.pdf 
Kidd, M.T., P.D. Gerard, J. Heger, B.J. Kerr and D. Rowe et al., 2001. Threonine and crude protein responses in broiler chicks. Anim. Feed Sci. Technol., 94: 57-64. DOI: 10.1016/S03778401(01)00301-7

Klasing, K.C., 1998. Nutritional modulation of resistance to infectious diseases. Poult. Sci., 77: 1119-1125. PMID: 9706075

Koide, K. and T. Ishibashi, 1995. Threonine requirement in female broilers. affected by age and dietary amino acid levels. Jap. Poult. Sci., 32: 329-336. rms1.agsearch.agropedia.affrc.go.jp/contents/JASI/ pdf/.../52-0343.pdf

Marjanovic, D., L. Kozic, M. Petrovic, T. Palic and V. Litricin, 1975. Serum transaminase activity in fowls. Vet. Bull., 45: 2890-2896. http://www.cababstractsplus.org/abstracts/Abstract. aspx?AcNo=19752283914

Meirelles, H.T., R. Albuquerque, L.M.O. Borgatti, L.W.O. Souza and N.C. Meister et al., 2003. Performance of broilers fed with different levels of methionine hydroxy analogue and DL-methionine. Rev. Bras Cienc Avic. 5: 69-74. DOI: 10.1590/S1516-635X2003000100009

Munro, H.N. and D.M. Goldberg, 1964. The Role of the Gastro-Intestinal Tract in Protein Metabolism, Munro, H.N. (Ed.). Black Wells Scientific Publications $\quad$ Oxford, pp: 209. http://www.annals.org/content/62/5/1104.3.full.pdf

Muramatsu, K., H. Odagiri, S. Morishita and H. Takeuchi, 1971. Effect of excess levels of individual amino acids on growth of rats fed casein diets. J. Nutr., 101: 1117-1125. http://jn.nutrition.org/cgi/reprint/101/9/1117

National Research Council, 1994. Nutrient Requirement of Poultry. 9th Rev. Edn., National Academy Press, Washington, DC., ISBN: 13: 9780-309-04892-7, pp: 176.

Ngo, A. and C.N. Coon, 1976. The effect of feeding various levels of dietary glycine in a pre experimental diet to one-day old chicks on their subsequent glycine plus serine requirement. Poult. Sci., 55: 1672-1677. PMID: 995799

Ojano-Dirain, C.P. and P.W. Waldroup, 2002. Evaluation of lysine, methionine and threonine. needs of broilers three to six week of age under moderate temperature stress. Int. J. Poult. Sci., 1: 16-21. http://www.pjbs.org/ijps/fin5.pdf

Paaw, J.D. and A.T. Davis, 1990. Taurine concentrations in serum of critically injured patients and age-and sex-matched healthy control subjects. Am. J. Clin. Nutr., 5: 814-822. http://www.ajcn.org/cgi/reprint/52/4/657
Quentin, M., I. Bouvarel and M. Picard, 2005. Effects of starter diet, light intensity and essential amino acids level on growth and carcass composition of broilers. J. Applied Poult. Res., 14: 69-76. http://japr.fass.org/cgi/reprint/14/1/69

Rama Rao, S.V., N.K. Praharaj, R.V. Ramasubba and A.K. Panda, 2003. Interaction between genotype and dietary concentrations of methionine for immune function in commercial broilers. Br. Poult. Sci., 44: 104-112. DOI: $10.1080 / 0007166031000085283$

Robbins, K.R., 1987. Threonine requirement of broiler chicks as affected by protein level and source. Poult. Sci., 66:1531-1534. PMID: 3120170

Shini, S., X. Li and W.L. Bryden, 2005. Methionine requirement and cell-mediated immunity in chicks. Asia Pac. J. Clin. Nutr., 14: S123. http://apjen.nhri.org.tw/server/APJCN/ProcNutSoc/ 2000+/2005/vol14supp.pdf

Smith, N.K. and P. Waldroup, 1988. Investigations of threonine requirements of broiler chicks fed diets based on grain sorghum and soybean meal. Poult. Sci., 67: 108-112. PMID: 3131754

Swain, B.K. and T.S. Johri, 2000. Effect of supplemental methionine, choline and their combinations on the performance and immune response of broilers. Br. Poult. Sci., 41: 83-88. DOI: 10.1080/0007166008645

Thomas, O.P., P.V. Twining Jr., E.H. Bossard, J.L. Nicholson and M. Rubin, 1979. Broiler chick studies with threonine and lysine. Proceedings of the 1979 Maryland Nutrition Conference, University of Maryland, College Park, MD., USA., pp: 44-48. http://jn.nutrition.org/cgi/reprint/112/11/2170.pdf

Virtanen, E. and L. Rosi, 1995. Effects of betaine on methionine requirement of broiler under various environmental conditions. Proceedings of the 8th of the Australian Poultry Science Symposium, University of Sydney, Sydney New, Australia, pp: $\quad$ 88-92. http://www.cabi.org/animalscience/Uploads/File/A nimalScience/additionalFiles/WPSAVerona $\% 5 \mathrm{C} 10$ 361.pdf

Williams, B., S. Solomon, D. Waddington, B. Thorp and C. Farquharson, 2000. Skeletal development in the meat-type chicken. Br. Poult. Sci., 41: 141-149. DOI: $10.1080 / 713654918$

Zwarenstein, H., 1926. Studies in creatinine and uric acid metabolism. Biochem. J., 20: 743-750. http://www.ncbi.nlm.nih.gov/pmc/articles/PMC125 1778/pdf/biochemj01149-0096.pdf 